\title{
The use of bioassays to assess the toxicity of sediment in an acid mine drainage impacted river in Gauteng (South Africa)
}

\author{
P Singh'*, A Nel' and JF Durand' \\ 'Department of Zoology, University of Johannesburg, Auckland Park, Johannesburg 2006, S.A
}

\begin{abstract}
Sediment contamination may occur from various anthropogenic activities, such as mining-, agricultural- and industrial practices. Many of the contaminants arising from these activities enter the aquatic system and precipitate from the surrounding water, becoming bound to sediment particles. These bound contaminants may reach concentrations higher than in the overlying water. Although water quality may be acceptable, an aquatic system may still be at risk if the contaminated sediment were to be disturbed through flooding, bioturbation or changes in the water chemistry. These contaminants may then desorb into the water column and prove detrimental to life forms in contact and dependent on that water source. Sediment quality monitoring has been a widespread international initiative and has led to the development of sediment toxicity assessment methods. This study focused on sediment bioassays, namely, Phytotoxkit, Ostracodtoxkit F and the Diptera bioassay, in assessing sediment quality of the Tweelopiespruit-Rietspruit-Bloubankspruit river system in Gauteng, South Africa. This river is known to have been impacted by acid mine drainage (AMD) since late August, 2002. Exposure of river sediment from 7 sampling sites to these bioassays provided an eco-toxicological estimation of the acute toxicity and chronic toxicity emanating from the contaminated sediments. Physico-chemical analyses revealed higher levels of sediment contamination closer to the mine. The bioassays displayed a similar trend with greater sensitivities to sediments closer to the mine and lower sensitivities to the less contaminated sites further downstream. AMD was therefore the main driver for sediment contamination. Whilst not all contaminants were bioavailable, statistical analysis showed that there were significant correlations between the elevated contaminant concentrations closer to the mine and bioassay responses.
\end{abstract}

Keywords: acid mine drainage, sediment toxicity, bioassay, Ostracodtoxkit F, Phytotoxkit, Diptera bioassay

\section{INTRODUCTION}

Ecological disturbances in the natural environment are caused by various anthropogenic activities. Such activities include industrial processes, agricultural practices, mining, pharmaceuticals and urban run-off (Aguilar et al., 2004; Antunes et al., 2007; Miller and Spoolman, 2009). Contaminants emanating from these activities pollute water resources and result in deleterious impacts on aquatic ecosystems. These contaminants may remain in the water column, whilst a variable quantity may descend to the benthic layer. Over time, and depending on the physico-chemistry of the water source, accumulation of contaminants may occur in the water column and result in a greater concentration of contaminants in the sediment, to harmful levels. Hence, sediment acts as a source and sink for various contaminants.

The Tweelopiespruit-Rietspruit-Bloubankspruit (TRB) river system has been polluted by acid mine drainage (AMD) emanating from the abandoned Harmony Gold Mine, upstream of Krugersdorp Game Reserve, along the Tweelopiespruit, since August 2002. Historically, the TRB river has been impacted by AMD water at an estimated rate of $36 \mathrm{~mL} /$ day. The outcome of such a substantial amount of acidic, metal-rich discharge resulted in the decline of benthic biodiversity, decimation of marginal and aquatic vegetation, and a rapid reduction in water quality, as well as negative impacts to other aquatic and terrestrial life dependent on the river (Durand, 2012).

Gold has been mined from auriferous layers along the Witwatersrand Basin since its discovery in 1886 (Durand,

To whom all correspondence should be addressed.

푱 +27768194518; e-mail: prasheensingh@yahoo.com Received 14 October 2015; accepted in revised form 11 October 2017
2012). Acid mine drainage is produced from the biological and chemical reactions when pyrite is exposed to oxygen and water and may be intensified by extensive fragmentation of rocks during excavation and milling of rocks. In the presence of water and atmospheric oxygen, oxidation and hydrolysis of pyrite (FeS2) produces sulphuric acid and a ferrichydrite precipitate (Eq. 1) (Durand, 2012; Blowes et al., 2014).

$\mathrm{FeS}_{2}(s)+\left(\frac{15}{4}\right) \mathrm{O}_{2}(a q)+\left(\frac{7}{2}\right) \mathrm{H}_{2} \mathrm{O}(a q) \rightarrow 2 \mathrm{SO}_{4}^{2-}+\mathrm{Fe}(\mathrm{OH})_{3}(s)+4 \mathrm{H}^{+}(a q)$

The ferrichydrite precipitate forms a thick, impermeable layer covering the river sediment and is commonly called 'yellow boy' due to the yellow-orange appearance it gives to the river bed (Durand, 2012). AMD is characterised by a low $\mathrm{pH}$, high concentrations of metals and other toxic elements, as well as a high specific conductivity (Akcil and Koldas, 2006).

Contaminated sediments can be defined as sediments with chemical substances, exceeding the threshold value that would pose a known or supposed threat to environmental and/ or human health (Power and Chapman, 1992). The major risk involving sediment contamination is the re-suspension of sediment-bound contaminants into the water column at concentrations much higher than permitted by water quality guidelines. This potential risk to aquatic ecosystems increases, depending on the physical, chemical and biological characteristics of the water source. An increase in the flow rate, changes in $\mathrm{pH}$ and water chemistry, are some factors that may induce desorption and re-suspension of contaminants, thereby increasing the bioavailability (Burton, 1992).

Power and Chapman (1992) summarised the interaction between contaminated toxic sediments and benthic organisms. The uptake of contaminants may occur across the body wall and accompanied by respiratory processes from the overlying 
and pore water, and through ingestion of contaminated sediment particles. Accumulation in the organism and interaction with the receptor site(s) within the organism may result in various biological effects. The uptake and biological effects expressed are both dependent on the bioavailability of the toxic contaminant(s). According to the National Research Council (NRC, 2003), chemical, physical and biological factors influencing the interactions between organisms and sediment-bound contaminants are termed bioavailability processes (Fig. 1).

Process ' $E$ ' is the most ecotoxicologically significant, representing the fate of the contaminant(s) once inside the organism and initiation of expressed/measurable toxic effects (NRC, 2003).

Effective sediment toxicity monitoring utilises both physico-chemical and bioassays to predict probable effects of specific contaminants on the environment, humans and ecological receptors (NRC, 2003; Blaise and Ferard, 2005). Numerous ecotoxicological studies have been conducted to develop a variety of physico-chemical and bioassay methods.

The Phytotoxkit is a 3-day acute sediment toxicity bioassay developed by MicroBioTests and involves the exposure of 1 monocotyledon species, Sorghum saccharatum, and 2 dicotyledon species, Lepidium sativum and Sinapis alba, to either contaminated sediments, soils, solid phase wastes, chemicals or biocides. Endpoints include seed germination inhibition, root length inhibition and shoot length inhibition (MicroBioTests Inc., 2004). The decimation of primary producers may negatively impact the entire aquatic ecosystem; hence assessing the impact on this trophic level is imperative (Antunes et al., 2007). This bioassay has been previously used to assess the toxicity of petroleum hydrocarbons (Van der Vliet et al., 2012), sewage sludge compost (Oleszczuk, 2008), eutrophic freshwater, $\mathrm{Cr}(\mathrm{VI})$ with cyclodextrin, boric acid (Czerniawska-Kusza, 2011) and sediments contaminated with heavy metals, polycyclic aromatic hydrocarbons, and organic and inorganic contaminants (Czerniawska-Kusza et al., 2006).

The Ostracodtoxkit F is a 6-day direct contact sediment toxicity bioassay also developed by MicroBioTests. In this bioassay, the freshwater ostracod Heterocypris incongruens is exposed to contaminated sediment and/or water. Endpoints include mortality and growth inhibition. Ostracods form an important component of aquatic meiofauna, therefore their sensitivity and survival necessitates the use of this bioassay, which has been used to assess the toxicity of chemicals, wastes, sewage sludge compost, sediments, inorganic and organic pollutants (MicroBioTests Inc., 2001; Oleszczuk, 2008). The sensitivity of $H$. incongruens has been found to be similar to Hyalella azteca and Chironomus riparius (MicroBioTests Inc., 2001; Belgis et al., 2003).

The Diptera bioassay is generally conducted over 10 days and involves the exposure of either Chironomus riparius or Chironomus tentans to sediment and/or soil (USEPA, 1994; Bedard and Ali, 1996). In the current study, a South African Chironomidae species, Chironomus caffrarius, was used (Cloete and Shaddock, 2012). This bioassay is a whole sediment direct contact toxicity test which has been used to evaluate the toxicity of sediment polluted with metals, AMD, oils, grease, inorganic and organic compounds, and polycyclic aromatic hydrocarbons (Bedard and Ali, 1996; Adendorff, 1997; Pery et al., 2005). Endpoints include mortality and growth inhibition (Bedard and Ali, 1996; Environment Canada, 1997).

For the purposes of this study, the Phytotoxkit, Ostracodtoxkit F and Diptera bioassay, accompanied by physico-chemical analyses, were used to assess the toxicity of sediment along the TRB river.

\section{MATERIALS AND METHODS}

\section{Study area and sampling}

The study area is situated in the West Rand of Gauteng and 7 sampling sites were selected during July 2013 along the TRB river (Fig. 2). The TRB river flows north along the Tweelopiespruit, from the locus of decant (LoD) in the vicinity of Harmony Gold Mine, passes through the Krugersdorp Game Reserve and, after its confluence with the Rietspruit (from the West), becomes the Bloubankspruit. The latter then flows eastward, passing through the Cradle of Humankind World Heritage Site (COHWHS), feeding the Crocodile River which then empties into Hartbeespoort Dam.

Sampling Sites 1 to 4 were identified in the Tweelopiespruit. Sites 5 and 6 were identified in the Bloubankspruit (Fig. 2). Municipal wastewater enters the Bloubankspruit upstream of Site 5 whilst Site 6 is the furthest downstream from the LoD at the mine (Fig. 2). Site 7, the reference site, was selected along the Honingklipspruit, which enters the Bloubankspruit upstream of Site 6 (Fig. 2).
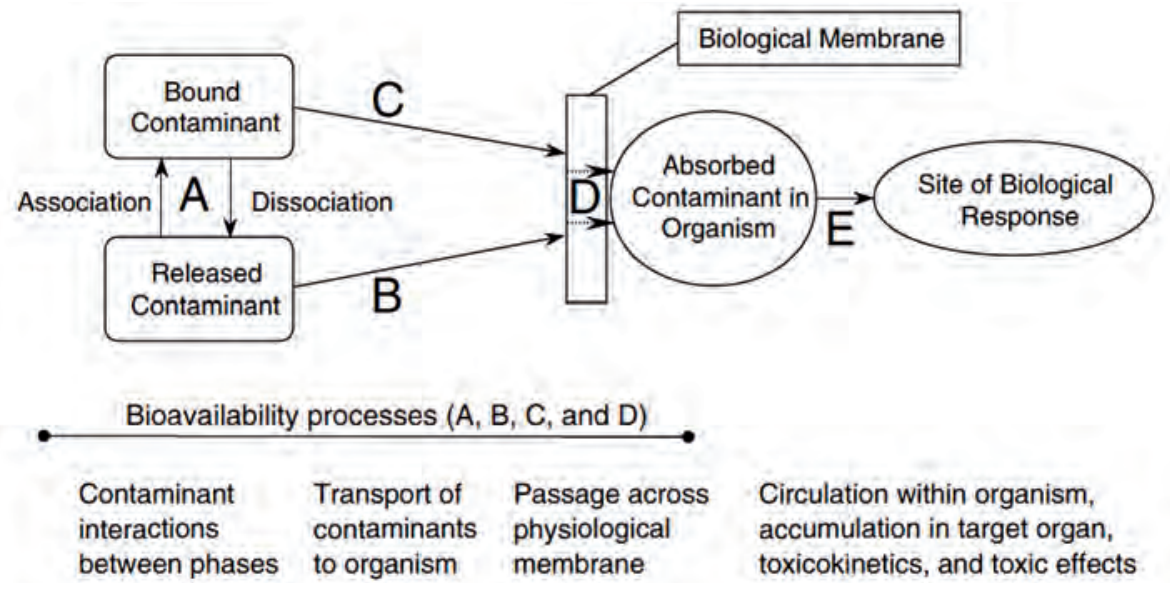

Circulation within organism, accumulation in target organ, toxicokinetics, and toxic effects

Figure 1

Bioavailability processes influencing contaminant transfer, transport and uptake (adapted from NRC, 2003) 
Sediment samples were collected using an Ekman-type grab sampler for the sampling of the top $2 \mathrm{~cm}$ of the sediment layer (recent deposition) (USEPA, 2001). Sampling containers were filled with sediment and thereafter filled to the brim with overlying water from the site. All samples were transported in a portable ice chest and stored at the laboratory at -20 until further analysis.

\section{Physico-chemical analyses}

Sediment samples were analysed for total organic carbon (TOC), moisture content, particle size distribution, and total element concentrations. Standard operating procedures (SOP) were followed when performing these analyses. Sediment from each study site was homogenised prior to analysis. TOC was analysed following the loss-on-ignition method in a Labcon Muffle Furnace (ASTM, 2000). The moisture content was calculated by measuring the difference between wet weight and dry weight of the sediment samples (Yee et al., 1992). The samples were weighed on an analytical balance before and after oven-drying and being placed in a desiccator. Particle size distribution was determined using a shaker and mesh sizes of $4000 \mu \mathrm{m}, 2000 \mu \mathrm{m}, 500 \mu \mathrm{m}, 212 \mu \mathrm{m}, 53 \mu \mathrm{m}$, as well as a collector tray to collect sediment less than $53 \mu \mathrm{m}$ (Cyrus et al., 2000). Aqua regia digestion of the sediment samples (Chen and Ma, 2001) preceded inductively coupled plasma-optical emission

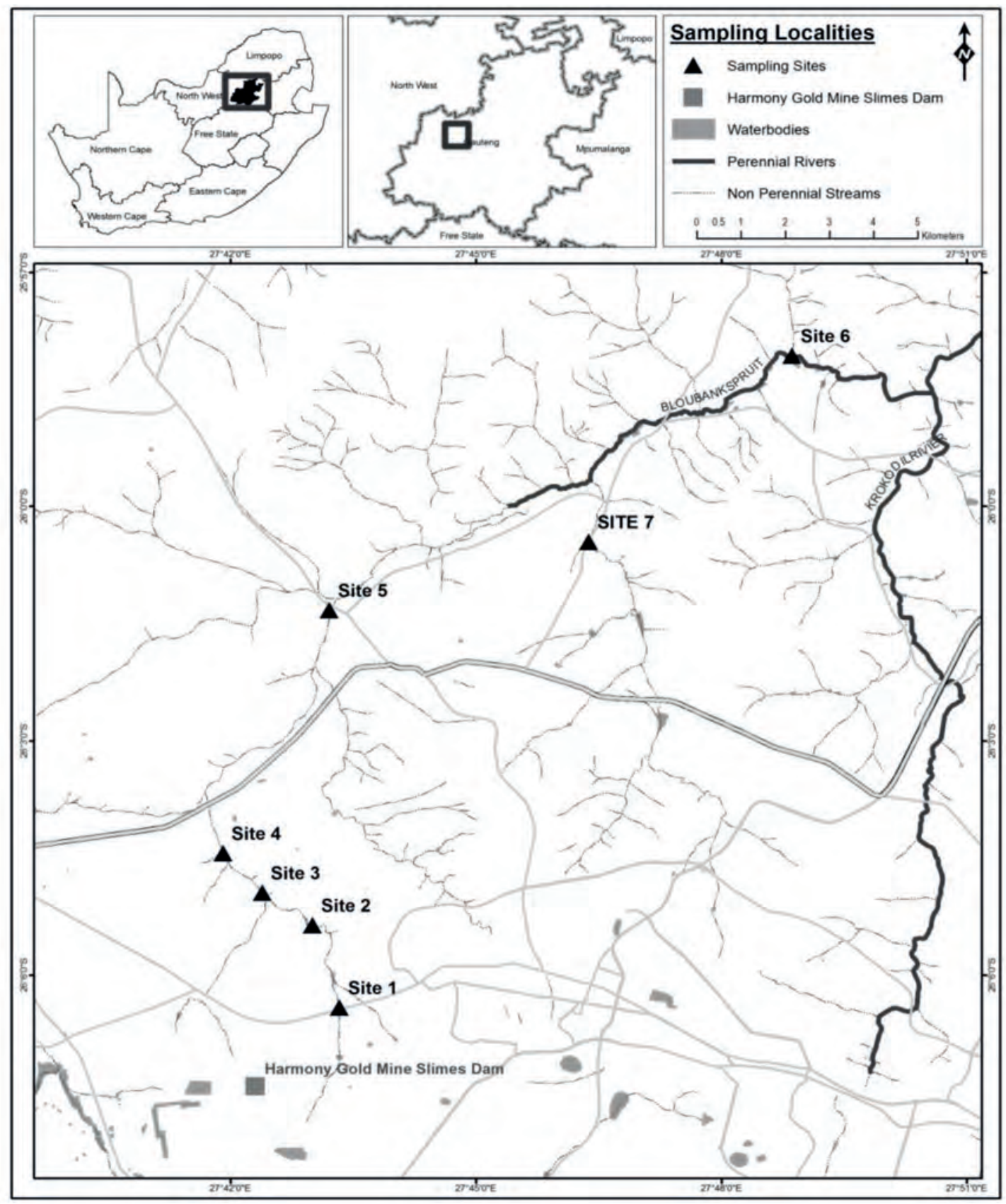

Figure 2

The study area and sediment sampling localities along the TRB river system 
spectroscopy (ICP-OES) analysis performed using a Perkin Elmer Optima 2100DV. This analysis focused on 34 elements in the sediment following the methodology stipulated in ISO 11885: 1996 (ISO, 1996). Quality assurance was maintained by the ICP instrument passing the scheduled quality control tests with a multi-element aqueous CRM (certified reference material).

\section{Phytotoxkit bioassay}

The Phytotoxkit exposures were carried out following the SOP published by MicroBioTests Inc. (MicroBioTests Inc., 2004). Sediment samples were prepared for the exposures by homogenising, air drying (oven drying at $60^{\circ} \mathrm{C}$, where required), and then sieving through a $2 \mathrm{~mm}$ sieve to remove debris and organic material. The water-holding capacity of each sample was calculated to determine the volume of reverse osmosis water needed for complete saturation. The test and control exposures were performed in duplicate; hence a total of 20 seeds per plant species were exposed. According to the SOP, $90 \mathrm{~cm} 3$ of the sediment was placed and levelled in the test plate, followed by the addition of the calculated amount of reverse osmosis water, filter paper, and then seed placement. These test plates were then incubated for 3 days at $25 \pm 2^{\circ} \mathrm{C}$, in darkness. After the incubation period, test plates were scanned using a flat-bed scanner and stored electronically for data analysis. Root length measurements were determined using ImageJ (ver. 1.460) software. To test the validity of the bioassay the controls for each plant species had to have a mean seed germination of $\geq 70 \%$ and a minimum mean root length of $\geq 30 \mathrm{~mm}$ (MicroBioTests Inc., 2004).

\section{Ostracodtoxkit F bioassay}

The Ostracodtoxkit F exposures were carried out following the SOP published by MicroBioTests Inc. (MicroBioTests Inc., 2001). Sediment samples were prepared for toxicity testing as described for the Phytotoxkit bioassay. The following were added into each multi-well plate: two $500 \mu \mathrm{L}$ measures of test sediment, $2 \mathrm{~mL}$ standard freshwater, $2 \mathrm{~mL}$ algal food suspension and 10 ostracods. The test and control exposures were performed in duplicate, exposing 20 test organisms to each sediment sample. These multi-well test plates were then incubated for 6 days at $25 \pm 2^{\circ} \mathrm{C}$, in darkness. After the incubation period, surviving ostracods were recovered, fixed using Lugol solution and then image captured using a digital light microscope. Length measurements were determined using ImageJ (ver. 1.460) software. To test the validity of the test, the controls had to present a mean percentage mortality of $\leq 20 \%$ and a mean ostracod length that increased by a factor of 1.5 (MicroBioTests Inc., 2001).

\section{Diptera bioassay}

The bioassay methodology was adapted from available international methodologies (Bedard and Ali, 1996; U.S. EPA, 2000; Antunes et al., 2007; Cloete and Shaddock, 2012; Shaddock, 2013). Test organisms were collected from a breeding monoculture from the Golder Associates Research Laboratory. Sediment samples were prepared for toxicity testing as described for the Phytotoxkit bioassay. Prior to starting the test, test vessels were filled with test sediment and reverse osmosis water (1:4) and left to stand overnight to reach equilibrium. Using a Pasteur pipette, 10 larvae (10-12 days old) were carefully placed into each test vessel. The 10-day exposure was done in an environmental room with controlled conditions $\left(21 \pm 2^{\circ} \mathrm{C}\right.$ and $16 \mathrm{~h}: 8 \mathrm{~h}$ light-dark cycle). The bioassay was performed in duplicate, exposing 20 test organisms to each sediment sample. After the 10 -day test duration, percentage mortality was determined using the surviving chironomids.

\section{Data analysis and hazard classification system}

Data obtained from the analytical and toxicity tests were analysed using specially formulated Microsoft Excel worksheets. TOC was calculated using Eq. 2.

$$
\operatorname{TOC}(\%)=\frac{(\text { Dryweight }- \text { inorganic weight })}{\text { Dryweight }} \times 100
$$

Moisture content of the sediment was calculated using Eq. 3.

Moisture content $(\%)=\frac{(\text { Wet weight }- \text { Dry weight })}{\text { Wet weight }} \times 100$

The formula used to determine seed germination inhibition (GI) and root length inhibition (RI) observed with the Phytotoxkit is presented in Eq. 4.

$$
G I(\%) \text { or } R I(\%)=\frac{A-B}{A} \times 100
$$

where $A=$ mean seed germination or root length in the control reference sediment

and $B=$ mean seed germination or root length in the test sediment

Percentage mortality and percentage growth inhibition observed from the Ostracodtoxkit F exposures were determined using Eqs 5 and 6, respectively.

$$
G I(\%) \text { or } R I(\%)=\frac{A-B}{A} \times 100
$$

Where $A=$ total number of surviving ostracods.

$$
\begin{aligned}
& \text { Growth Inhibition }(\%)= \\
& \quad: 100-\left(\frac{\text { Growth in test sediment }}{\text { growth in control sediment }} \times 100\right)
\end{aligned}
$$

Percentage mortality observed from the Diptera bioassay was determined using Eq. 7.

$$
\operatorname{Mortality}(\%)=\frac{n}{20} \times 100
$$

Where, $n=$ number of dead organisms

The hazard classification system (Table 1) developed by Persoone et al. (2003) was used to classify toxicity of sediment along the TRB river based on response data from sediment bioassays. Equation 8 was used to determine the class weight score percentage.

$$
\begin{aligned}
& \text { Class weight score } \%= \\
& \qquad 100-\left(\frac{\text { Growth in test sediment }}{\text { growth in control sediment }} \times 100\right)
\end{aligned}
$$




\section{Sediment quality guidelines}

The Canadian Freshwater Sediment Quality Guidelines (CCME, 2002) include the Threshold Effect Level (TEL) and the Probable Effect Level (PEL). The TEL is the concentration below which no effect may be observed whilst concentrations above the PEL may result in adverse biological effects. The second guideline was developed by, and explained by ANZECC and ARMCANZ (2000), and includes the Severe Effect Level (SEL). Concentrations above the SEL have the potential to eradicate the majority of benthic organisms. The Upper Crust Average (UC) was also used for comparison, as it represents the naturally occurring average composition of elements in the upper continental crust. These sediment guideline limits are presented in Table 2 and only include the values for the elements addressed in this study.

\section{Statistical analysis}

Multivariate statistical analysis was incorporated to get a holistic understanding of the toxicity of the seven sites. An unconstrained principle component analysis (PCA), using Canoco v5 (Ter Braak and Smilauer, 2012), was selected to represent the data. All data included in the analysis were log transformed to ensure homogeneity. The PCA with supplementary variables analysed the correlations between the sites, bioassay responses and physico-chemical variables of the sediment.

\section{RESULTS AND DISCUSSION}

Historic pollution of the TRB river system has severely impacted the biotic and abiotic components of the environment. Previous studies of the river system by Hobbs and Cobbing (2007), Beringer et al. (2012) and Durand (2012) confirmed pollution as a result of AMD. These studies focused mainly on water quality and biomonitoring. The current study aimed to assess the potential impacts of the polluted sediment.

Particle size of sediments is known to influence toxicity. There is an increased probability of sorption and desorption of contaminants to fine sediments, due to a larger surface area (Power and Chapman, 1992, Apitz et al., 2002, Owens et al., 2005). The particle size distribution of sediment from each site is graphically presented in Fig. 3. A higher percentage of finer grained sediments (smaller than $212 \mu \mathrm{m}$ ) were found closer to the LoD at the mine, possibly a result of AMD, the associated iron hydroxide precipitates, and sedimentation of weathered/eroded underground rocks. Larger particles (greater than $500 \mu \mathrm{m}$ ) were more prevalent further downstream.

A correlation was observed between particle size distribution and percentage moisture content (Table 3; Fig. 4), i.e., increased moisture content existed with a higher percentage of finer-grained particles. The total organic carbon (the amount of oxidisable organic material in sediments) represents the nonionic organic chemical bioavailability (USEPA, 2001). Organic carbon was present in sediment samples from all seven sites (Table 3). Metal bioavailability may be affected by TOC in sediment (USEPA, 2001) as metals in sediments form soluble and insoluble organic complexes (Fig. 4) (Burton, 1992).

Concentrations of $\mathrm{Al}, \mathrm{As}, \mathrm{Ca}, \mathrm{Cr}, \mathrm{Fe}, \mathrm{Ni}, \mathrm{S}$ and $\mathrm{U}$ in the sediment samples are presented in Table 3 . These elements have a high probability of being associated with AMD and may be ecologically relevant. Various other elements were also present in the TRB system, but are not presented.

In South Africa, aluminium occurs naturally at high concentrations and, although below the Upper Crust Average (UC) of $77440 \mathrm{mg} / \mathrm{kg}$ (Wedepohl, 1995), was present at a high concentration of $45200 \mathrm{mg} / \mathrm{kg}$ at Site 1 with an almost linear decrease to $7400 \mathrm{mg} / \mathrm{kg}$ at Site 5 (Table 3). The reference site (Site 7), however, presented an aluminium concentration of $23000 \mathrm{mg} / \mathrm{kg}$, which was much higher than the concentrations recorded at the other sites. This is still below the UC, and may be attributed to the surrounding geology and activities relative to the catchment.

Arsenic in the system may have originated as a waste product of gold-mining activities whereby gold was extracted from arsenical pyrite (Durand, 2015; Blowes et al., 2014). Arsenic present as Sites 1-3 possibly originates from AMD and increased from $21 \mathrm{mg} / \mathrm{kg}$ at Site 1 to $40 \mathrm{mg} / \mathrm{kg}$ at Site 3, suggesting that the contamination could have dispersed downstream due to heavy rainfall in the study area (ANZECC and ARMCANZ, 2000; Lusilao-Makiese, et al., 2013). The presence of arsenic at Site 5 could be attributed to discharge from the

\begin{tabular}{|l|c|c|c|c|}
\hline \multicolumn{5}{|c|}{$\begin{array}{c}\text { TABLE } 2 \\
\text { Sediment quality guideline limits. Adapted from CCME } \\
\text { (2002) and ANZECC and ARMCANZ (2000) }\end{array}$} \\
\hline \multirow{2}{*}{ Element } & \multicolumn{2}{|c|}{ Sediment quality guidelines (mg/kg) } \\
\cline { 2 - 5 } & TEL & PEL & SEL & UC \\
\hline Aluminium (Al) & - & - & - & 77440 \\
\hline Arsenic (As) & 5.9 & 17 & 33 & 2.0 \\
\hline Calcium (Ca) & - & - & - & 29450 \\
\hline Chromium (Cr) & 37.3 & 90 & 110 & 35 \\
\hline Iron (Fe) & - & - & - & 30890 \\
\hline Nickel (Ni) & 18 & 36 & 75 & 18.6 \\
\hline Sulphur (S) & - & - & - & 953 \\
\hline Uranium (U) & - & - & - & 2.5 \\
\hline
\end{tabular}

- No guideline limit

TABLE 1

Hazard classification system. Adapted from Persoone et al. (2003)

\begin{tabular}{|c|c|c|c|}
\hline Percentage effect (PE) & Class & Hazard & Symbol \\
\hline$\leq 20 \%$ & Class I & No acute hazard & (:) \\
\hline $20 \% \leq \mathrm{PE} \leq 50 \%$ & Class II & Slight acute hazard & $\ddot{\theta}$ \\
\hline $50 \% \leq \mathrm{PE} \leq 100 \%$ & Class III & Acute hazard & ? \\
\hline PE $100 \%$ in at least one test & Class IV & High acute hazard & @ê \\
\hline PE $100 \%$ in all tests & Class V & Very high acute hazard & @e \\
\hline
\end{tabular}




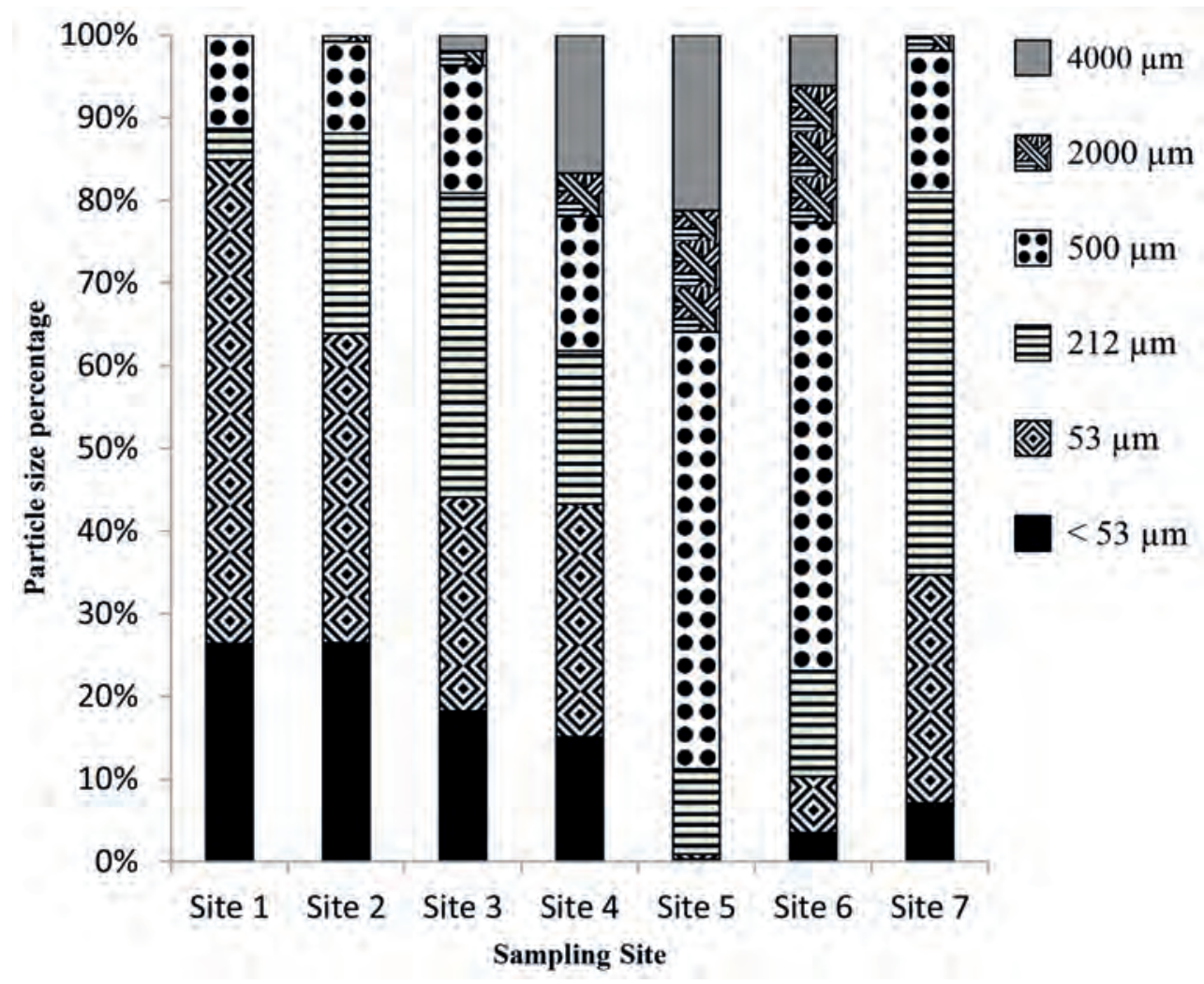

Figure 3

Particle size distribution of sediment sampled from the seven sites along the acid mine drainage impacted TRB river system

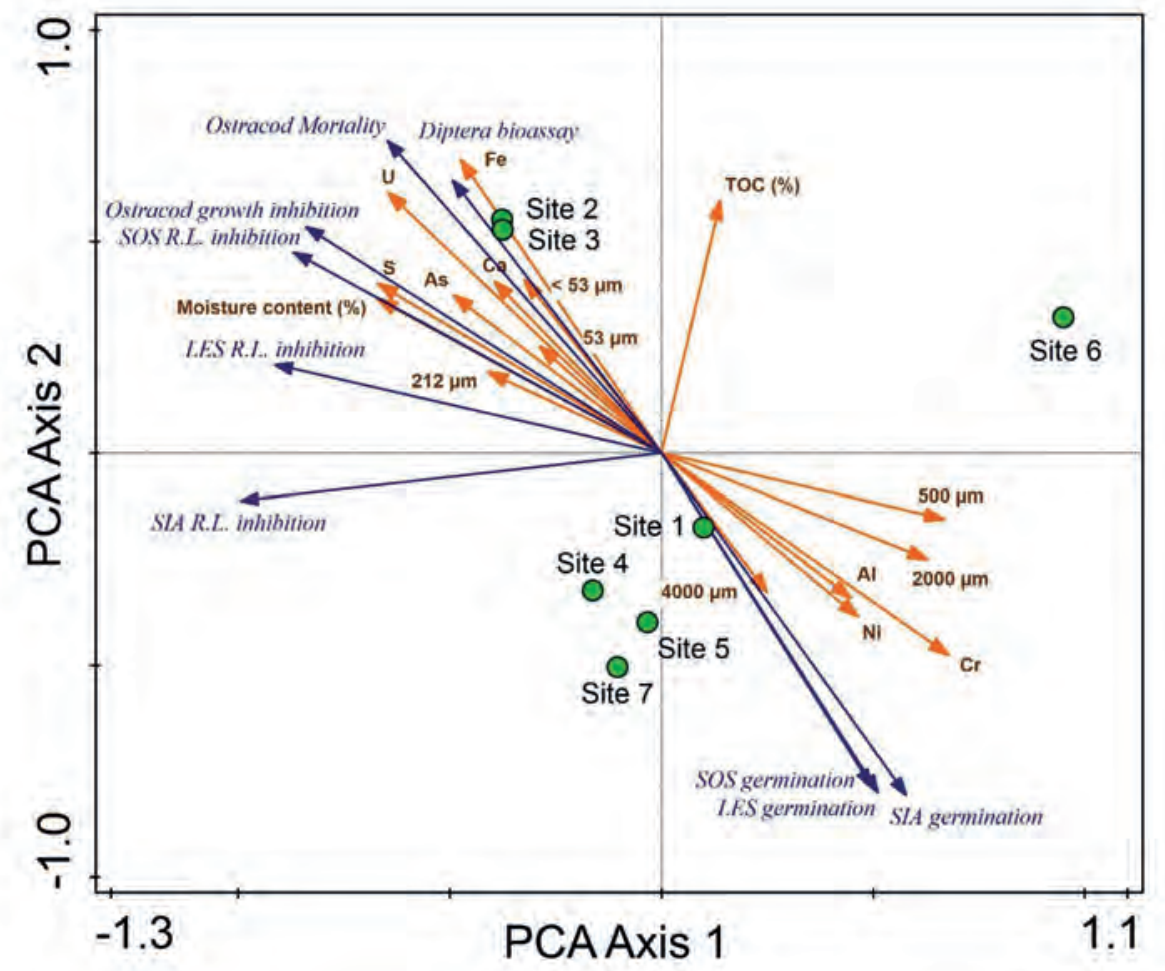

Figure 4

PCA ordination diagram of bioassay responses and physico-chemical variables of sediment from Sites 1 to 7 along the TRB river 
waste-water treatment works (WWTW) entering the TRB system upstream of Site 5, as wastewaters tend to contain arsenic (Sullivan, 2010). At Sites 1, 2 and 5 arsenic concentrations were above the PEL (CCME, 2002), whilst at Site 3 these were above the SEL (ANZECC and ARMCANZ, 2000). Arsenic levels were below the detection limit in the sediment at the reference site.

A decrease in calcium concentrations was observed from Site $1(36600 \mathrm{mg} / \mathrm{kg})$ to Site 5 (1 $000 \mathrm{mg} / \mathrm{kg})$. Sediment from Site 1 and 2 contained calcium above the UC. These high levels may be attributed to the dissolution of dolomite by AMD (Durand, 2012), as well as the treatment of AMD with limestone (Riefler et al., 2008). In comparison to the first 4 sites, the reference site presented a much lower calcium concentration.

Chromium levels exceeded the TEL at Sites 3 and 4, the PEL at Site 1, and the SEL at Sites 5, 6 and 7 (Table 3). Higher concentrations were found downstream, with a spike at Site 6. A possible explanation for this could be due to chromium contamination along the Honingklipspruit (as seen with Site 7), conveying chromium into the TRB system upstream of Site 6 . However, chromium may have not been in a bioavailable form.

The UC level for iron was exceeded at all sites, except Site 5 (Table 3). Iron is a major element of the earth's crust and therefore may occur naturally at high concentrations in sediments (DWAF, 1996). Despite this, elevated levels may become prevalent as a result of AMD (Durand, 2012). A decrease in iron concentrations was observed from Site $2(355000 \mathrm{mg} / \mathrm{kg})$ through to Site $5(22800 \mathrm{mg} / \mathrm{kg})$. Iron is an essential micronutrient for organisms, but toxic effects may arise depending on the state of iron, i.e., ferric or ferrous state (DWAF, 1996). The iron concentration at the reference site was much lower compared to the first 4 sites, and comparable to the levels observed at sites further downstream from the mine.

The PEL for nickel was exceeded at Sites 1 and 5, and the SEL at Sites 3, 4, 6 and 7 (Table 3). Nickel may originate from the weathering of minerals and rocks (ANZECC and ARMCANZ, 2000) and anthropogenically through AMD from mining (Durand, 2012). Nickel is an essential trace element but high levels may prove fatal to organisms. Nickel toxicity increases with a decrease in $\mathrm{pH}$ (ANZECC and ARMCANZ, 2000).

Sulphur was present in sediment sampled at all sites, and elevated levels were observed at Sites 1 to 4 . A linear decrease in sulphur suggested AMD as the origin as sulphates are released from pyrite (Durand, 2012). Sulphur plays an important role in binding metals and organics, therefore it may be quite influential to the expressed toxicity (ANZECC and ARMCANZ, 2000). Sulphur in the sediment could also be related to the sulphates and contaminant-sorbed sulphates that have been deposited. The sulphur concentration at the reference site was significantly lower when compared to sites closer to the mine.

Uranium is a radioactive element present in AMD which produces toxic effects to aquatic biota and humans (ANZECC and ARMCANZ, 2000; Durand, 2012). Uranium was present at Sites 2, 3 and 4 (Table 3). A linear decrease was observed from $34 \mathrm{mg} / \mathrm{kg}$ at Site 2 , to $14 \mathrm{mg} / \mathrm{kg}$ at Site 4 , indicating AMD from the gold mine as the potential source. Uranium concentrations were below the detection limit at Sites 5, 6 and 7 (reference site). The Phytotoxkit displayed some sensitivity to sediments contaminated with AMD (Fig. 4; 5). Phytotoxicity was estimated as a function of seed germination (lethal endpoint) (Fig. 5) and root length inhibition (sub-lethal endpoint) (Fig. 6). The Phytotoxkit bioassay met the test validity criteria for germination and root growth. Sediment from Sites 2 and 3 were most toxic to seed germination, whilst sediment sampled further downstream of the LoD (Site 6) presented lower toxicity responses. Site 1 , although closest to the LoD, only presented a slight inhibitory effect on L. sativum germination. No significant inhibition of seed germination occurred at Sites 4 to 6 and the reference site (Site 7). The overall trend of expressed lethal toxicity indicated elevated toxicity at the sites closer to the mine LoD, and decreasing downstream.

A similar observation could be seen when analysing data generated from root length inhibition responses (Fig. 6). The highest inhibitory effect was observed at Sites 2 and 3 for all three plant species. Root length inhibition at these sites ranged between $93 \%$ and $100 \%$. Root length stimulation occurred with S. alba and L. sativum at Site 1, whilst 32\% inhibition was observed for S. saccharatum. Site 6 presented the lowest phytotoxicity with root length stimulation occurring for L. sativum and S. alba, and a slight inhibition for S. saccharatum (Fig. 6). Although phytotoxicity of sediment was low at Site 1, the two subsequent sites presented extremely high toxicities followed by a general linear decrease in root length inhibition from Site 4 to 6 , inferring sub-lethal toxicity caused by AMD. Significant root length inhibition also occurred at the reference site, as root length inhibition for L. sativum and S. alba exceeded 30\%, suggesting the presence of bioavailable contaminants.

Expressed toxicity by plants can be attributed to sediment organic matter (Oleszczuk, 2008; Bakopoulou et al., 2011) and metals such as manganese, copper, zinc, iron and chromium (Bakopoulou et al., 2011). High organic matter content in sediments may increase the absorption potential of metals, thereby increasing the potential bioavailability (Czerniawska-Kusza and Kusza, 2011). Organic material binds metals forming soluble and insoluble complexes and depending on the interactions that occur, metals may or may not be bioavailable (Burton, 1992). Plant growth may be stimulated by nitrogen and phosphorus while inhibited by ammonia (Baran and Tarnawski, 2013). Phyto-stimulation occurs in the presence of nutrient-rich sediments and may result in the elimination of the inhibitory effects of heavy metals on plant growth (Czerniawska-Kusza and Kusza, 2011).

Sub-lethal and lethal phytotoxicity was higher at sites closer to the mine, whilst phyto-stimulation occurred with sediments sampled further downstream of the mine. In addition, the responses corresponded to the particle grain size, i.e., higher toxicities occurred where small grain sizes (smaller than $212 \mu \mathrm{m}$ ) were prevalent (Fig. 4). Therefore, the toxicity expressed with the Phytotoxkit to the sediment samples may be related to contaminants in the sediment and the high percentage of small sediment particles, which supported the findings of Czerniawska-Kusza et al. (2006). Phytotoxicity effects expressed in relation to metal contaminants are complex and depend on the remobilisation mechanisms that control metal bioavailability for root uptake (Czerniawska-Kusza et al., 2006). Baran and Tarnawski (2013) also found a positive correlation between metal concentrations and toxicity for L. sativum and S. alba.

Phytotoxicity at Site 1 was lower than at Sites 2 and 3. This may be due to treatment operations that commenced prior to the time of sampling and/or the presence of potassium in the sediment. Potassium concentrations from Site $1-7$ were $1320,460,1260,1800,460,2000$ and $1000 \mathrm{mg} / \mathrm{kg}$, respectively. Potassium is fundamental in metabolic reactions and plant growth (Czerniawska-Kusza and Kusza, 2011). Therefore, phyto-stimulation may have occurred at some of the sites (such as Site 6) as a result of high potassium concentrations coupled with other nutrients such as phosphorus and nitrogen (Czerniawska-Kusza and Kusza, 2011; Baran and Tarnawski, 
TABLE 3

Physico-chemical analyses of sediments sampled along the acid mine drainage impacted TRB river system. Total organic carbon (TOC) (\%), moisture content (\%), and concentration of each element ( $\mathrm{mg} / \mathrm{kg}$ ).

\begin{tabular}{|l|c|c|c|c|c|c|c|}
\hline \multirow{2}{*}{ Parameter } & \multicolumn{4}{|c|}{ Decreasing proximity from mine's LoD } & Reference site \\
\cline { 2 - 9 } & Site 1 & Site 2 & Site 3 & Site 4 & Site 5 & Site 6 & Site 7 \\
\hline TOC (\%) & 5.72 & 14.31 & 11.57 & 10.34 & 1.14 & 17.06 & 8.45 \\
\hline Moisture content (\%) & 33.2 & 61.7 & 52.7 & 48.9 & 18.4 & 23.2 & 43.5 \\
\hline $\mathrm{Al}$ & 45200 & 4600 & 14600 & 17800 & 7400 & 23200 & 23000 \\
\hline $\mathrm{As}$ & 21 & 24 & 40 & $<2.00$ & 30 & $<2.00$ & $<2.00$ \\
\hline $\mathrm{Ca}$ & 36600 & 35000 & 11800 & 9800 & 1000 & 3000 & 5000 \\
\hline $\mathrm{Cr}$ & 96 & 20 & 73 & 80 & 119 & 333 & 319 \\
\hline $\mathrm{Fe}$ & 39000 & 355000 & 271600 & 209200 & 22800 & 54800 & 30800 \\
\hline $\mathrm{Ni}$ & 65 & 6.00 & 92 & 82 & 44 & 126 & 108 \\
\hline $\mathrm{S}$ & 28200 & 46000 & 24800 & 7600 & 150 & 72 & 373 \\
\hline $\mathrm{U}$ & $<2.00$ & 34 & 30 & 14 & $<2.00$ & $<2.00$ & $<2.00$ \\
\hline
\end{tabular}

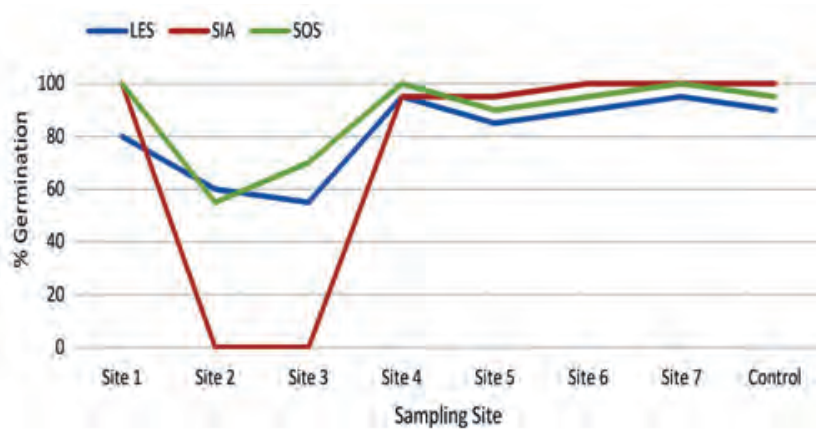

Figure 5

Percentage seed germination observed with the Phytotoxkit exposure to sediment from Sites 1 to 7 along the TRB river system study area. (LES - Lepidium sativum; SIA - Sinapis alba; SOS - Sorghum saccharatum)

2013). Sediments closer to the mine LoD were therefore toxic to primary producers in the ecosystem. In previous studies by Durand (2012) and Bell et al. (2001), severe impacts to vegetation had occurred in AMD-contaminated systems.

The Ostracodtoxkit $\mathrm{F}$ met the validity criteria as the mean percentage mortality in the controls did not exceed $20 \%$ and the mean length of the ostracods in these controls increased by a factor of 1.5. The trend in sub-lethal (growth inhibition) and lethal (mortality) toxicity was comparable to the Phytotoxkit responses; higher expressed toxicities closer to the mine and decreasing linearly towards the downstream sites. The highest toxicity effect was observed at Sites 2 and 3, with $100 \%$ mortality at both sites followed by a linear decrease in mortality and growth inhibition towards Site 6 (Fig. 7). At Sites 5, 6 and 7 growth stimulation occurred, suggesting that the sediments from these sites were favourable for the survival and growth of the ostracods. Although some metals were elevated at Site 1, and higher than the concentrations observed at Sites 2 and 3, the lack of effect could be due to metal bioavailability (Havel and Talbott, 1995).

Toxicity expressed by the Ostracodtoxkit F bioassay also corresponded to the particle size distribution since higher toxicities were observed at the sites with a higher percentage of small grain sizes (less than $212 \mu \mathrm{m}$ ). This suggested that sediment-bound contaminants could be the main cause of

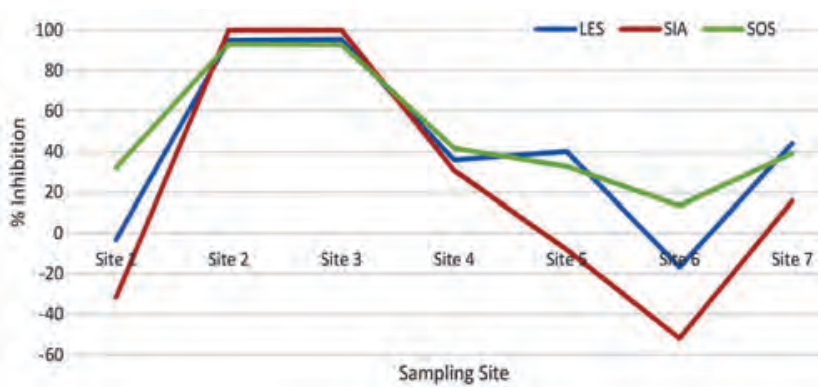

Figure 6

Percentage root length inhibition observed with Phytotoxkit exposure to sediment from Sites 1 to 7 along the TRB river system study area. (LES - Lepidium sativum; SIA - Sinapis alba; SOS - Sorghum saccharatum)

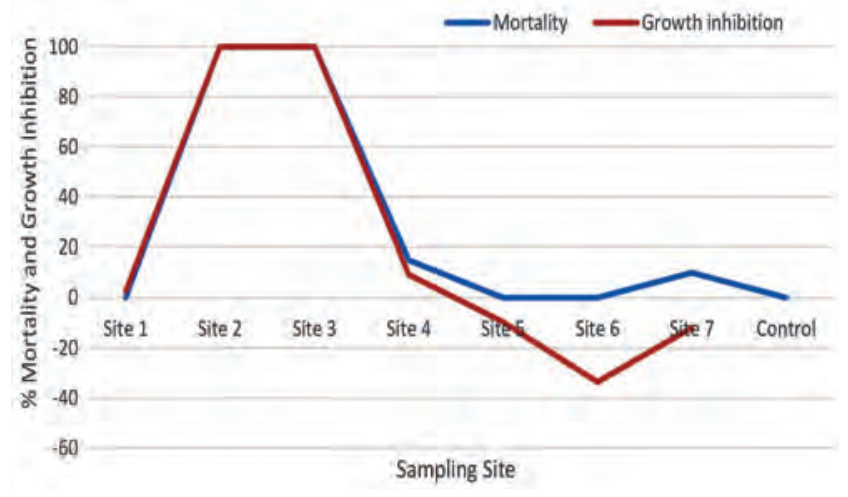

Figure 7

Percentage mortality and growth inhibition observed with Ostracodtoxkit F bioassay (Heterocypris incongruens) exposure to sediment from Sites 1 to 7 along the TRB river system study area.

toxicity. Sites 2 and 3 presented high TOC and metal concentrations (Table 3 ). Therefore, toxicity may have been caused by organic material-bound metals that are bioavailable. According to Oleszczuk (2008), H. incongruens displayed high sensitivity to metals and is comparable to Hyalella azteca and $C$. riparius (MicroBioTests Inc., 2001). Although the reference 
site presented $10 \%$ mortality, growth stimulation of $11.98 \%$ occurred. The expressed toxicities showed a positive correlation to sediment contamination (Fig. 4).

The Diptera bioassay met the test validation criteria and presented a decrease in lethal toxicity from sites closest to the mine to downstream sites (Fig. 8). Percentage mortality increased from $75 \%$ at Site 1 to $100 \%$ at Site 2 followed by a linear decrease to $25 \%$ at Site 6 . Mortality within the Tweelopiespruit (Sites 1-4) ranged between 50 and100\%. Although C. caffrarius was not as sensitive to the contamination at Site 3, compared to the Phytotoxkit and Ostracodtoxkit, it displayed a higher response to sediment contamination at Site 1 (Fig. 8). C. caffrarius may therefore be more sensitive to AMD-related contaminants than the other two bioassays. This may be due to feeding habits of this test organism: larval stages of Chironomidae are substrate particle feeders, ingesting food particles (e.g. total organic carbon from organic debris) together with sediment (Adendorff, 1997). The sedimentbound contaminants may then accumulate in the organism, resulting in mortality responses. Low mortalities were observed at the reference site (Fig. 8), indicating lower toxicity.

The general trend of toxicity for the Diptera bioassay was similar to the first two bioassays, presenting a linear decrease in lethal toxicity from sites closer to the mine LoD towards downstream sites. Chironomus species have shown sensitivities to metal-contaminated sediments (USEPA, 2000) therefore the mortalities of $C$. caffrarius may be attributed to metals in the sediment along with other contaminants that have not been identified. Adendorff (1997) further found that Chironomus species accumulated higher metal concentrations, in comparison to organisms belonging to Hydropsychidae, Ephemeroptera, Trichoptera, Plecoptera, Gerridae and Gyrinidae, due to the ingestion of sediment. In a study by Antunes et al. (2007), higher toxicity was observed when using mine effluent as the overlying water in a sediment bioassay instead of synthetic hard water. The former may alter the physico-chemical properties and systematically affect the bioavailability of sediment-bound contaminants.

An additional observation to the Diptera bioassay (not graphically presented) was the occurrence of growth inhibition at Sites 1, 3 and 4, where test organisms were smaller than those exposed to the downstream sites along the TRB river and control. Growth of test organisms may be affected by feeding (Pery et al., 2005) and/or responses to bioavailable contaminants (Ingersoll et al., 2001). The former was not the case as growth inhibition was only observed with sediment closer to the mine (Sites 1, 3 and 4, and 100\% mortality at Site 2). Hence, sub-lethal toxicity observed with the Diptera bioassay could be linked to AMD-related sediment contamination, whereby size and growth of benthic invertebrates may be inhibited.

The hazard classification system designed by Persoone et al. (2003) summarised the responses of the three bioassays and classified the seven sites based on the highest expressed toxicity (Table 4). The hazard classification suggested that sites along the TRB river closer to the mine were more hazardous to flora and fauna, which was also confirmed by the physicochemical analyses. Therefore, toxicity may be attributed to AMD. Toxicity at Site 1 may be lower than Site 2 as a result of improved conditions from effective remediation. At the time of the study, Sites 2 and 3 were the most affected sites with a linear decrease in toxicity towards sites furthest away from the mine (Table 4).

Multivariate statistical analysis using the PCA method was used to produce the ordination diagram in Fig. 4. Axis 1

\begin{tabular}{|c|c|c|c|}
\hline $\begin{array}{l}\mathrm{Haz} \\
\text { im } \\
\text { fron }\end{array}$ & $\begin{array}{l}\text { TABLE } 4 \\
\text { d classification of } 7 \text { sites alon } \\
\text { cted TRB river system, based } \\
\text { he Phytotoxkit, Ostracodtoxk }\end{array}$ & $\begin{array}{l}\text { ee acid } n \\
\text { respons } \\
\text { and Dip }\end{array}$ & $\begin{array}{l}\text { drainage } \\
\text { cquired } \\
\text { bioassay }\end{array}$ \\
\hline Site & Acute hazard class & Symbol & $\begin{array}{c}\text { Class } \\
\text { weight } \\
\text { score \% }\end{array}$ \\
\hline 1 & Class III - acute hazard & ? & $(30.0 \%)$ \\
\hline 2 & Class IV - high acute hazard & @e & $(73.3 \%)$ \\
\hline 3 & Class IV - high acute hazard & \&0 & $(66.7 \%)$ \\
\hline 4 & Class III - acute hazard & ? & $(50 \%)$ \\
\hline 5 & Class II - slight acute hazard & 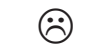 & $(80 \%)$ \\
\hline 6 & Class II - slight acute hazard & 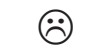 & $(60 \%)$ \\
\hline 7 & Class I - no acute hazard & (:) & $(60 \%)$ \\
\hline
\end{tabular}

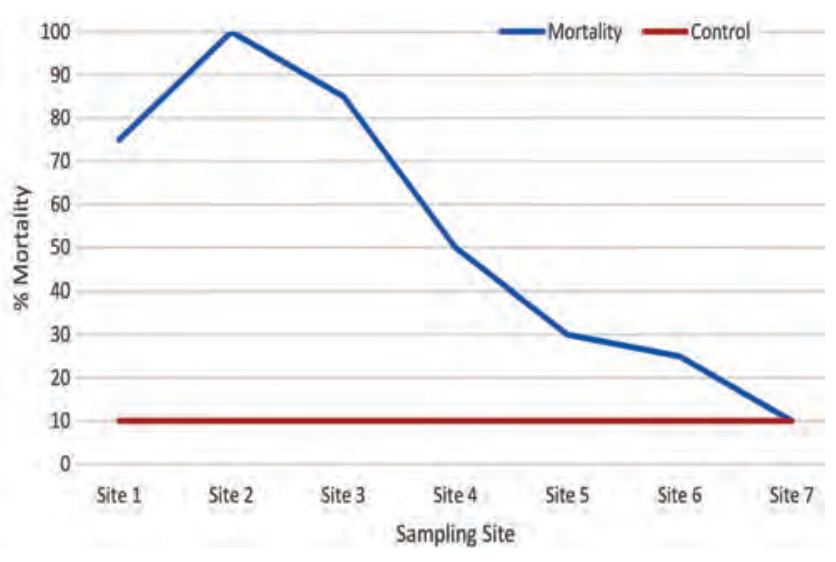

Figure 8

Percentage mortality after 10-day Chironomus caffrarius (Diptera bioassay) exposure to sediment from Sites 1 to 7 along the TRB river system study area

explains $90.07 \%$ of the variation whilst Axis 2 explains $8.49 \%$. Cumulatively, the plot explains $98.56 \%$ of the variation within the data. A correlation existed between lethal and sublethal bioassay responses and higher contaminant concentrations such as Fe, U, S, and As closer to the mine (Sites 2 and 3). The proportions of smaller grained sediments $(<212 \mu \mathrm{m})$ correlated with higher moisture content, TOC and contaminant concentrations. Seed germination showed a negative correlation to the same contaminants, indicating that As, Fe, $\mathrm{S}$ and $\mathrm{U}$ are possible drivers for the expressed toxicity. The grouping of Sites 1, 4, 5 and 7 indicates a negative correlation to the toxicity drivers as the contaminant concentrations were lower at these sites. A negative correlation existed between Site 6 , sediment contaminants, drivers and bioassay responses. This was expected as Site 6 is spatially furthest from the mine LoD. The grouping of $\mathrm{Al}, \mathrm{Ni}$ and $\mathrm{Cr}$ correlated with larger particle sizes, but may not be related to the seed germination responses due to reduced bioavailability as these metals showed a negative correlation to the toxicity drivers, lethal and sublethal bioassay responses. 


\section{CONCLUSIONS}

Sediment contamination is a global concern since contaminants may accumulate to, and reach toxic levels in, the sediment. Factors affecting the interactions between contaminants and sediment may systematically release the pollutants, resulting in detrimental impacts to the various compartments of the environment, including human health. This may arise from pollution of the water resource as a result of contaminant concentrations exceeding the water quality guidelines. Ecological risks associated with mining waste, such as AMD, may be rated second only to global warming (Manders et al., 2009). The findings of this study confirmed observations of previous studies which alluded to detrimental impacts along the TRB river system caused by AMD emanating from the abandoned Harmony Gold Mine since August 2002.

The Phytotoxkit, Ostracodtoxkit F and Diptera bioassay all displayed high sensitivity to sediment contamination as a result of AMD. A reduction in some contaminants (As, Ca, $\mathrm{Fe}$ and $\mathrm{U})$ and small sediment particles $(<212 \mu \mathrm{m})$ resulted in a decrease in sensitivity of the bioassays to sediment at the downstream sites, further away from the mine, where lower mortalities and even growth stimulation occurred. C. caffrarius was most sensitive to AMD-related contaminants in the sediment. The sensitivities of the bioassays can be arranged as follows: Ostracodtoxkit F < Phytotoxkit < Diptera bioassay. The Phytotoxkit and Ostracodtoxkit F also showed high sensitivity to sediment contaminated by AMD; therefore no trophic-level specificity was present. The sensitivity of the individual experimental species can be concluded as follows: $S$. alba $<$ L. sativum $<H$. incongruens $<$ S. saccharatum $<$ C. caffrarius. Higher lethal and sub-lethal toxicity was expressed to sediments collected closer to the mine. This indicated that sediment toxicity in the TRB river may have originated from AMD decanting into the system.

The hazard classification system revealed that sediment sampled from Sites 1 to 4 (closer to the mine) presented an acute to high acute hazard to the aquatic environment, whilst Site 6 (furthest downstream) presented a slight acute hazard. Sediment at the reference site (Site 7) presented no acute hazard to the aquatic environment. From the bioassay results it was evident that sediment in the TRB river system closer to the mine will not support plant growth and may prevent the existence of aquatic invertebrates. This in turn may negatively impact the entire ecosystem.

The PCA ordination diagram presented a positive correlation between lethal (and sublethal) responses, smaller particle size, and high contaminant concentrations, TOC and moisture content.

Sediment along the TRB river system (especially closer to the mine) was therefore contaminated by AMD to harmful levels which were above that of the reference site (healthy, no acute hazard), which has resulted in a decrease in the aquatic health of this river system.

\section{ACKNOWLEDGEMENTS}

The authors would like to express their gratitude to the Water Research Commission, Golder Associates Research Laboratory and the University of Johannesburg for funding, guidance, support and/ or laboratory facilities required throughout this study.

\section{REFERENCES}

ADENDORFF A (1997) Effects of mining activities on selected aquatic organisms. PhD thesis, Rand Afrikaans University.

AGUILAR J, DORRONSORO C, FERNANDEZ E, FERNANDEZ J, GARCIA I, MARTIN F and SIMON M (2004) Soil pollution by a pyrite mine spill in Spain: evolution in time. Environ. Pollut. 132 395-401. https://doi.org/10.1016/j.envpol.2004.05.028

AKCIL A and KOLDAS S (2006) Acid mine drainage (AMD): causes, treatment and case studies. J. Cleaner Prod. 14 1139-1145. https:// doi.org/10.1016/j.jclepro.2004.09.006

ANTUNES SC, DE FIGUEIREDO DR, MARQUES SM, CASTRO BB, PEREIRA R and GONCALVES F (2007) Evaluation of water column and sediment toxicity from an abandoned uranium mine using a battery of bioassays. Sci. Total Environ. 374 252-259. https:// doi.org/10.1016/j.scitotenv.2006.11.025

ANZECC and ARMCANZ (Australia and New Zealand Environment and Conservation Council and Agriculture and Resource Management Council of Australia and New Zealand) (2000) Australian and New Zealand Guidelines for Freshwater and Marine Quality. Volume 2: Aquatic Ecosystems - Rationale and Background Information. ANZECC and ARMCANZ, Artarmon.

APITZ SE, DAVIS JW, FINKELSTEIN K, HOHREITER DL, HOKE R, JENSEN RH, MACK EE, STAHL R, JERSAK J, MAGAR V and co-authors (2002) Critical Issues for Contaminated Sediment Management. MESO-02-TM-01. United States Navy, California.

ASTM (American Society for Testing and Materials) (2000) Standard Test Methods for Moisture, Ash, and Organic Matter of Peat and Other Organic Soils. Method D2974-00. American Society for Testing and Materials, West Conshohocken.

BAKOPOULOU S, EMMANOUIL C and KUNGOLOS A (2011) Assessment of wastewater effluent quality in Thessaly region, Greece, for determining its irrigation reuse potential. Ecotoxicol. Environ Saf. 74 188-194. https://doi.org/10.1016/j. ecoenv.2010.06.022

BARAN A and TARNAWSKI M (2013) Phytotoxkit/Phytotestkit and Microtox as tools for toxicity assessment of sediments. Ecotoxicol. Environ Saf. 98 19-27. https://doi.org/10.1016/j.ecoenv.2013.10.010

BEDARD D and ALI H (1996) Evaluation of the 10-Day Sediment Toxicity Test using the Midge (Chironomus tentans): The Effect of Different Water-Sediment Ratios on Biological Endpoints and Water Quality. Ontario Ministry of Environment and Energy, Ontario.

BELGIS CZ, PERSOONE G and BLAISE C (2003) Cyst-based toxicity tests XVI - sensitivity comparison of the solid phase Heterocypris incongruens microbiotest with the Hyalella azteca and Chironomus riparius contact assays on freshwater sediments from Peninsula Harbour (Ontario, Canada). Chemosphere 52 95-101. https://doi.org/10.1016/S0045-6535(03)00186-3

BELL FG, BULLOCK SE, HÄLBICH TF and LINDSAY P (2001) Environmental impacts associated with an abandoned mine in the Witbank Coalfield, South Africa. Int. J. Coal Geol. 45 195-216. https://doi.org/10.1016/S0166-5162(00)00033-1

BERINGER G, DE KLERK M and TRUSLER G (2012) Draft scoping report for the immediate and short term interventions for the treatment of acid mine drainage (AMD) in the Western, Central and Eastern Basins of the Witwatersrand Gold Fields. DEA ref \#: 12/1220/2403. Digby Wells and Associates/The Trans-Caledon Tunnel Authority, Johannesburg.

BLAISE C and FERARD J-F (2005) Contemporary toxicity testing. In: Blaise C and Ferard J-F (eds) Small-scale Freshwater Toxicity Investigations: Volume 1. Springer, Dordrecht.

BLOWES DW, PTACEK CJ, JAMBOR JL, WEISENER CG, PAKTUNC D, GOULD WD and JOHNSON DB (2014) Revision: the geochemistry of acid mine drainage. In: Turekian KK and Holland HD (eds.) Treatise on Geochemistry (2nd edn.). Elsevier, Netherlands.

BURTON GA (1992) Sediment collection and processing: factors affecting realism. In: Burton GA (ed.) Sediment Toxicity Assessment. Lewis Publishers Inc., Chelsea.

CCME (Canadian Council of Ministers of the Environment) (2002) Canadian Sediment Quality Guidelines for the Protection of Aquatic Life: Summary Tables. Updated. In: Canadian 
Environment Quality Guidelines, 1999. Canadian Council of Ministers of the Environment, Winnipeg.

CHEN M and MA (2001) Comparison of three aqua regia digestion methods for twenty Florida soils. Soil Sci. Soc. Am. J. 65 491-499.

CLOETE Y and SHADDOCK B (2012) The identification of a suitable culture organism to establish a bio-assay for evaluating sediment toxicity. WRC Report No. TT 532/12. Water Research Commission, Pretoria.

CYRUS DP, WEPENER V, MACKAY CF, CILLIERS PM, WEERTS SP and VILJOEN A (2000) The effect of intrabasin transfer on the hydrochemistry, benthic invertebrates and ichthyofauna of the Mhlathuze Estuary and Lake Nsezi. WRC Report No. 722/1/00. Water Research Commission, Pretoria.

CZERNIAWSKA-KUSZA I, CIESIELCZUK T, KUSZA G and CICHON A (2006) Comparison of the phytotoxkit microbiotest and chemical variables for toxicity evaluation of sediments. Environ. Toxicol. 21 367-372.

CZERNIAWSKA-KUSZA I and KUSZA G (2011) The potential of the Phytotoxkit microbiotest for hazard evaluation of sediments in eutrophic freshwater ecosystems. Environ. Monit. Assess. 179 113-121.

DURAND JF (2012) The impact of gold mining on the Witwatersrand on the rivers and karst system of Gauteng and North West Province, South Africa. J. Afr. Earth Sci. 68 24-43. https://doi. org/10.1016/j.jafrearsci.2012.03.013

DWAF (Department of Water Affairs and Forestry, South Africa) (1996) South African Water Quality Guidelines Volume 7: Aquatic Ecosystems ( $2^{\text {nd }}$ edn). Department of Water Affairs and Forestry, Pretoria.

ENVIRONMENT CANADA (1997) Biological Test Method: Test for Survival and Growth in Sediment using Larvae of Freshwater Midges (Chironomus tentans or Chironomus riparius). Report: EPS 1/RM/32. Environmental Protection Series. Environment Canada, Canada.

HAVEL JE and TALBOTT BL (1995) Life history characteristics of the freshwater ostracod Cyprinotus incongruens and their application to toxicity testing. Ecotoxicology 4 206-218. https://doi.org/10.1007/ BF00116482

HOBBS PJ and COBBING JE (2007) The Hydrogeology of the Krugersdorp Game Reserve area and implications for the management of mine water decant. In: Proceedings of the Groundwater Conference, 8-10 October 2007, Bloemfontein.

INGERSOLL CG, MACDONALD DD, WANG N, CRANE JL, FIELD LJ, HAVERLAND PS, KEMBLE NE, LINDSKOOG RA, SEVERN C and SMORONG DE (2001) Predictions of sediment toxicity using consensus-based freshwater sediment quality guidelines. Arch. Environ. Contam. Toxicol. 41 8-21.

ISO (International Organization for Standardization) (1996) ISO 11885: Water Quality - Determination of 33 Elements by Inductively Coupled Plasma Atomic Emission Spectroscopy: Instrument Manual. International Organization for Standardization, Geneva.

LUSILAO-MAKIESE JG, CUKROWSKA EM, TESSIER E, AMOUROUX D and WEIERSBYE I (2013) The impact of post gold mining on mercury pollution in the West Rand region, Gauteng, South Africa. J. Geochem. Explor. 134 111-119. https://doi. org/10.1016/j.gexplo.2013.08.010

MANDERS P, GODFREY L and HOBBS P (2009) Acid mine drainage in South Africa. Briefing Note 2009/02. CSIR, Pretoria.

MICROBIOTESTS INC. (2001) OSTRACODTOXKIT F: Chronic "direct-contact" toxicity test for freshwater sediments. Standard Operational Procedure. MicroBioTests Inc., Mariakerke.

MICROBIOTESTS INC. (2004) PHYTOTOXKIT: Seed germination and early growth microbiotest with higher plants. Standard Operational Procedure. MicroBioTests Inc., Mariakerke.

MILLER GT and SPOOLMAN SE (2009) Environmental problems, their causes, and sustainability. In: Miller GT and Spoolman SE (eds) Living in the Environment: Concepts, Connections, and Solutions $\left(16^{\text {th }}\right.$ edn). Brooks/Cole, Belmont.

NRC (National Research Council) (2003) Bioavailability of Contaminated in Soils and Sediments. National Academy of Sciences, Washington.

OLESZCZUK P (2008) The toxicity of composts from sewage sludges evaluated by the direct contact tests Phytotoxkit and Ostracodtoxkit. Waste Manage. 28 1645-1653. https://doi. org/10.1016/j.wasman.2007.06.016

OWENS PN, BATALLA RJ, COLLINS AJ, GOMEZ B, HICKS DM, HOROWITZ AJ, KONDOLF GM, MARDEN M, PAGE MJ, PEACOCK DH and co-authors (2005) Fine-grained sediment in river systems: Environmental significance and management issues. River Res. Appl. 21 693-717. https://doi.org/10.1002/rra.878

PERSOONE G, MARSALEK B, BLINOVA I, TOROKNE A, ZARINA D, MANUSADZIANAS L, NALECZ-JAWECKI G, TOFAN L, STEPANOVA N, TOTHOVA L and co-authors (2003) A practical and user-friendly toxicity classification system with microbiotests for natural waters and wastewaters. Environ. Toxicol. 18 395-402.

PERY AR, MONS R and GARRIC G (2005) Chironomus riparius solidphase assay. In: Blaise C and Ferard JF (eds.) Small-scale Freshwater Toxicity Investigations: Volume 1. Springer, Dordrecht.

POWER EA and CHAPMAN PM (1992) Assessing Sediment Quality. In: Burton GA (ed.) Sediment Toxicity Assessment. Lewis Publishers Inc., Chelsea.

RIEFLER RG, KROHN J, STUART B and SOCOTCH C (2008) Role of sulfur-reducing bacteria in a wetland system treating acid mine drainage. Sci. Total Environ. 394 222-229. https://doi.org/10.1016/j. scitotenv.2008.01.024

SHADDOCK BF (2013) Development of a sediment quality triad approach to evaluate sediments in marine and freshwater environments of South Africa. PhD thesis, University of Johannesburg.

SULLIVAN CT (2010) Disposal of water treatment wastes containing arsenic - A review. Sci. Total Environ. 408 (8) 1770-1778. https:// doi.org/10.1016/j.scitotenv.2010.01.010

TER BRAAK CJF and SMILAUER (2012) Canoco v5, Windows release (5.00). Software for multivariate data exploration, testing and summarization. Biometris, Plant Research International. Wageningen, Netherlands.

USEPA (United States Environmental Protection Agency) (1994) Methods for Measuring the Toxicity and Bioaccumulation of Sediment-Associated Contaminants with Freshwater Invertebrates. USEPA 600/R-94/024. USEPA, Minnesota.

USEPA (United States Environmental Protection Agency) (2000) Methods for Measuring the Toxicity and Bioaccumulation of Sediment-associated Contaminants with Freshwater Invertebrates. U.S. EPA 600/R-99/064. USEPA, Minnesota.

USEPA (United States Environmental Protection Agency) (2001) Methods for Collection, Storage and Manipulation of Sediments for Chemical and Toxicological Analysis: Technical Manual. EPA823-B-01-002. USEPA, Washington.

VAN DER VLIET L, VELICOGNA J, PRINCZ J and SCROGGINS R (2012) Phytotoxkit: A critical look at a rapid assessment tool. Environ. Toxicol. Chem. 31 316-323.

WEDEPOHL KH (1995) Ingerson Lecture: The composition of the continental crust. Geochim. Cosmochim. Acta 59 (7) 1217-1232. https:// doi.org/10.1016/0016-7037(95)00038-2

YEE S, VAN RIKXOORT M and MCLEAY D (1992) The effect on holding time on Eohaustorius washingtonianus during ten-day sediment bioassays and reference toxicant tests. Environment Canada and Inter-Governmental Aquatic Toxicity Group, North Vancouver. 